exclusively on 2-carbon addition or rernoval at the carboxyl end of the fatty acid chain, making no reference to acids with an odd number of carbon atoms or to $\omega$-oxidation. This is not a criticism, since the authors at the outset define the limits of their subject and I myself share the editor's belief that "no worthwhile topic will remain overlooked for long". Allocation of more than 30 pages to the ehemistry of bacterial lipids in a book on metabolism is justified by the unusual nature of all the compounds described.

I feel confident that no reader, whether himself a lipid specialist or not, will fail to find all the contributions stimulating and adequate within their specified fields. The consistent pattern of the whole book, its clarity of expression, and its virtually complete freedom from misprints are a tribute to the editor no less than to the authors. It has been a pleasure to read it; it is a pleasure to recommend it unreservedly. J. A. LOVERN

' Popják, G., and Cornforth, J. W., Adv. Enzymol.,22, 281 (1960).

\section{SOUTHERN BRITAIN IN THE IRON AGE}

Map of Southern Britain in the Iron Age

Scale 1 : 625,000 (About Ten Miles to One Inch). (Chessington, Surrey: Director-Genoral of the Ordnance Survey, 1962.) Map and 56-page booklet, 17s. $6 d$. net; Map only, 7s. $6 d$.; Text only, $8 s$.

7 HE Ordnance Survey has recently issued a map of Iron Age sites in southern England. Along with John Betjeman's book of churches, the list of National Trust properties and the Automobile Association's Handbook, this publication should be in the dashboard cubbyhole of every interested motorist. It is, indeed, a very fine piece of work. Every Iron Age site of the 500 years before the coming of the Romans is categorized and mapped under various headings, each with its own symbol and colour to help distinguish the $A, B$ and $C$ and superimposed phases of the culture. No one can deny that the Iron Age in Britain was a very splendid period, and this work-it is much more than a mere map-gives at a glance an impression of its extent, importance and distribution.

The introduction describes the scope of the work, the way the map works with grid references, and gives an account of the characteristics of the things marked on it, for example, Belgic oppida, hill forts of various kinds, open settlements, lake villages, farms, fogous, shrines, cemeteries, barrows, burials, dykes, trackways and "Other Finds of Iron Age Material". It is unfortunate that no more than half a dozen lines could have been devoted to objects found at the sites or as isolated occurrences, especially as the introduction is followed by a splendid five-page article by D. F. Allen with two tables and eight full-page distribution maps devoted entirely to coin finds. While the Ordnance Survey keeps an index of small finds, it would have been most useful if even perhaps only the most important of these could have been mentioned under their sites in an extra column in the gazetteer. The Birdlip Mirror, for example, is a thing of great beauty-possibly one of the most beautiful works of art of its kind extant - but it and the many other beautifully and characteristically decorated objects that have been found are not mapped and barely referred to. When structures and coins are so well dealt with one cannot help regretting that the Celtic art-and art is the expression of culture - could not also have been catered for. On the cover of the bound edition some 30 characteristic objects are indeed incorporated, in colour, in a design, with a key to their provenance overleaf. But this is possibly misleading to the uninstructed amateur who may well think he will find information about them inside--it might have been more correctly indicative of the contents to have had drawings of hillforts, etc., or even a sketch of Maiden Castle, or a plan of Wandlebury Rings. But the specialist, of course, already knows all about Celtic art, and it is only the non-specialist who will suffer. This, after all, is a work of specialist importance. For students of the Iron Age and schoolteachers the splendid map is indispensable and O. G. S. Crawford would have rejojeed to see it. M. C. Burkitr

\section{THE CETACEANS}

Whales

By Prof. E. J. Slijper. Translated by A. J. Pomerans. Pp. 475. (London: Hutchinson and Co. (Publishors), Ltd., 1962.) 63s. net.

$\mathrm{N}$ this book, which is a revised translation of Prof Slijper's Walvissen published in Holland in 1958, the author has concentrated on the physiology, functional anatomy and behaviour of the Cetacea. These are subjects in which he has long been interested and on which he has worked not only in the laboratory and in northern waters but also during an antarctic whaling expedition in one of the great modern pelagic whalers. His industry over a great many years has resulted in the production of a book which appears to omit nothing that is known of these aspects of whale biology. The work is not addressed to the zoologist alone, but also aims to interest "the widest possible circle of readers in the life of animals which by their size, their strange habits, and the adventurous methods by which they are caught, have for many centuries captivated the imagination of mankind".

After a historical introduction, Prof. Slijper deals with the subdivisions of his subject in separate chapters, showing that an immense amount of new information has been discovered about the biology of whales during the past fifty years; he also indicates the wide and fascinating fiold that awaits further study by zoologists. His concluding chapter deals with the future of whales and whaling, a matter that leads beyond the paths of zoology into the realms of economics, big business and even politics.

The author has been fortunate in his translator, A. J. Pomerans, who has performed his task most skilfully so that the text flows as smoothly as if it had been originally written in English; Prof. Slijper's own linguistic skill has no doubt contributed much to this happy result.

The book is profusely illustrated with photographs and with very beautiful, clear line-drawings which add much to its value and, probably, to its rather high price. It concludes with an extensive select bibliography grouped under the subjects of each chapter, an arrangement which is not entirely to be commended because it is not a list of referencos, and the works of some of the authors quotod in the text are not to be found in it. The book will undoubtedly succeed in its aim of interesting a wide circle of readers in addition to zoologists who have specialized in studying the Cetacea. L. Harrison MATTHEws 